\title{
First report of grapevine Pinot gris virus infecting grapevine in Iran
}

\author{
Kimia Tokhmechi ${ }^{1} \cdot$ Davoud Koolivand $^{1}$ \\ Received: 24 July 2019 / Accepted: 3 October 2019/Published online: 18 October 2019 \\ (C) Società Italiana di Patologia Vegetale (S.I.Pa.V.) 2019
}

Keywords Grapeine Pinot gris virus · Coat Protein · Phylogentic analysis

Grapevine Pinot gris virus (GPGV) belongs to the genus Trichovirus in the Betaflexiviridae family (Fan et al. 2015). Reported for the first time in vineyards from Italy, this virus was subsequently detected in USA, Germany, Slovenia, Greece, Slovakia, Czech Republic, China, Thailand, South Korea and Turkey. In 2016-2017, green leaves and canes were collected from grapevines showing leaf deformation, mottling, vein clearing, and necrotic spots in various regions in Iran. To verify the presence of GPGV, total RNA was extracted (Gambino et al. 2008) and subjected to reverse transcription polymerase chain reaction (RT-PCR) with a pair of primers (GPGVF and GPGVR) (Fan et al. 2015) to amplify a part of the coat protein (CP) gene. An expected DNA fragment of about 500 bp was amplified from six of the 30 test samples. Infected cultivars included Askari, Bidane and Yaghouti in different grafted vineyards. The 24 samples that did not react to GPGV were primarily infected with grapevine fanleaf virus and arabis mosaic virus. The GPGV RT-PCR products were directly sequenced and the new sequences were deposited in GenBank as accession numbers MN199627 to MN199632. The results showed that CP gene sequences of
Iranian isolates showed identities ranging from 98.9 to $99.9 \%$ at nucleotide level. The Iranian isolates of GPGV had a high nucleotide identity ( 98.5 to $99.1 \%$ ) with GPGV isolates from Turkey and Hungary. Phylogenetic trees based on the CP gene sequence generated by Neighbor joining in MEGA6 confirmed that the Iranian GPGV isolates clustered with isolates from Turkey and Hungary. To the best of our knowledge this is the first report of grapevine Pinot gris virus from Iran.

\section{References}

Fan XD, Dong YF, Zhang ZP, Ren F, Hu GJ, Li ZN, Zhou JP (2015) First report of grapevine pinot gris virus in grapevines in China. Plant Dis 100:2

Gambino G, Perrone I, Gribaudo I (2008) A rapid and effective method for RNA extraction from different tissues of grapevine and other woody plants. Phytochem Anal 19:520-525

Publisher's note Springer Nature remains neutral with regard to jurisdictional claims in published maps and institutional affiliations.

Davoud Koolivand

Koolivand@znu.ac.ir

1 Department of Plant Protection, Faculty of Agriculture, University of Zanjan, Zanjan, Iran 